\title{
PERTANGGUNG JAWABAN PIDANA TERHADAP PELAKU TANPA IZIN MENGUMPULKAN LIMBAH OLI TANPA MELAKUKAN PENGELOLAAN
}

\author{
Steven Gozalex*, Kartina Pakpahan, Salim Pradana, Aldo Christian. T \\ Universitas Prima Indonesia \\ Jalan Sekip Sim. Sikambing, Medan, Sumatera Utara \\ stevengozalex1@gmail.com
}

\begin{abstract}
Everyone is prohibited from collecting B3 waste, especially oil, without the provision of a Minister, governor or regent/mayor in accordance with their authority. This is regulated in article 59 paragraph (4) and criminal sanctions are contained in article 102 of the UUPPLHD and in PP article 1 paragraph 2 Government Regulation No. 18 of 1999 concerning Management of Hazardous and Toxic Waste. B3 waste especially oil can damage the environment. This research uses normative juridical methodology with reference to secondary data sources as the main legal material analyzed and arranged systematically and then draws a descriptive conclusion. Specifically $B 3$ waste is the rest of the business and/or activity containing hazardous materials and/or toxic due to the nature and/or the concentration and / or amount, either directly or indirectly, can pollute and/or damage the environment, and/or can endanger the environment, health, the survival of humans and other living things. Oil as a dirty lubricant/oil, which by deliberately collected for resale to those who need it can damage the environment because sida from sediments dumped into the soil media can cause soil damage. The remaining oil must be processed or given to companies that can process waste so it is not dangerous. Actors can be responsible if there is an error in the guards, there is no forgiving and justifying element in the perpetrator and fulfills the subjective and objective elements of article 102 jo 59 paragraphs (4) Law Number 32 of 2009 concerning Environmental Management.
\end{abstract}

Keyword: Criminal liability, oil waste, collect without permission

\begin{abstract}
Abstrak
Setiap orang dilarang mengumpulkan limbah B3 khususnya oli tanpa ada izin dari Menteri, gubernur, atau bupati/walikota sesuai dengan kewenangannya. Hal ini di atur dalam Pasal 59 ayat (4) dan sanksi pidana terdapat dalam Pasal 102 UUPPLH Dan di dalam PP Pasal 1 ayat 2 Peraturan Pemerintah No. 18 tahun 1999 tentang Pengelolaan Limbah Bahan Berbahaya dan Beracun. Limbah B3 khusunya oli dapat merusak lingkungan. Penelitian ini menggunakan penelitian yuridis normatif dengan metodologi mengacu pada sumber data sekunder sebagai bahan hukum utama. Dianalisis dan disusun secara sistematis kemudian menarik suatu kesimpulan bersifat deskriptif. Secara spesifik limbah B3 merupakan sisa bisnis dan/atau aktivitas yang mengandung bahan berbahaya dan / atau beracun karena sifat dan / atau konsentrasi dan / atau jumlahnya, baik secara langsung maupun tidak langsung, dapat mencemari dan / atau merusak lingkungan, dan / atau dapat membahayakan lingkungan, kesehatan, kelangsungan hidup manusia dan makhluk hidup lainnya. Oli sebagai pelumas / minyak kotor, yang dengan sengaja dikumpulkan untuk dijual kembali kepada mereka yang membutuhkannya dapat merusak lingkungan karena sida dari sedimen dibuang ke media tanah dapat menyebabkan kerusakan tanah. Minyak yang tersisa harus diolah atau diberikan kepada perusahaan yang dapat memproses limbah sehingga tidak berbahaya. Pelaku dapat bertanggung jawab apabila terdapat kesalahan didalam diri sipelaku, tidak terdapat unsur pemaaf dan pembenar didalam diri pelaku dan memenuhi unsur subyektif dan obyektif dari pasal 102 jo. 59 ayat (4) Undang-Undang Nomor 32 Tahun 2009 Tentang Perlindungan Pengelolahan Lingkungan Hidup.
\end{abstract}

Kata Kunci: Pertanggungjawaban Pidana, Limbah Oli, Mengumpulkan Tanpa Izin 


\section{Pendahuluan}

Pembangunan membawa dampak perubahan yang terjadi sebagai akibat suatu aktivitas yang dapat bersifat alamiah, baik kimia, fisik maupun biologi. ${ }^{1}$ Dampak tersebut dapat bernilai positif dan negatif, negatif yaitu timbulnya resiko yang merugikan masyarakat. Menurut Manahan (1994) mengatakan sebuah benda yang berbahaya adalah material yang boleh jadi menghadirkan bahan berbahaya bagi kehidupan organisme, material, bangunan, atau lingkungan karena ledakan bahaya kebakaran, korosi, keracunan bagi organisme, maupun akibat yang menghancurkan. ${ }^{2}$ Terjadinya pencemaran tidak secara seketika tetapi melalui proses penurunan kualitas lingkungan secara bertahap. Diawali dengan pengotoran oleh materi atau zat tertentu dalam jangka waktu lama.

Menurut Munadjat Danusaputro, pencemaran adalah suatu keadaan, dimana zat atau energi diintroduksikan ke dalam lingkungan oleh kegiatan manusia atau proses alam sendiri menyebabkan terjadi perubahan mengakibatkan lingkungan tidak berfungsi yang merusak kesehatan, kesejahteraan dan keselamatan hayati. ${ }^{3}$ Limbah bengkel digolongkan sebagai limbah B3 karena mengandung bahan berbahaya dapat merusak, mencemari lingkungan membahayakan kesehatan manusia. ${ }^{4}$ Salah satu pencemaran B3 dapat berupa pelumas bekas/oli kotor, yang dengan sengaja dikumpulkan untuk dapat dijual kembali kepada yang membutuhkan perbuatan tersebut bertentangan dengan Peraturan perundang-undang. Besar kemungkinan pencemaran lingkungan oleh perbuatan tersebut oleh karena sida dari endapan dibuang ke media tanah, hal inilah yang mengakibatkan kerusakan tanah. Seharusnya sisa oli tersebut diolah atau diberikan kepada perusahaan yang dapat mengolah limbah tersebut sehingga tidak berbahaya. Apabila limbah B3 khususnya oli terus menerus terjadi dapat menimbulkan kerusakan terhadap kesehatan manusia oleh karena tercemarnya Limbah Oli bekas yang hasilkan dari proses pelapisan mesin memiliki kandungan logam berat seperti $\mathrm{Al}, \mathrm{Cr}, \mathrm{Cd}, \mathrm{Cu}, \mathrm{Fe}, \mathrm{Pb}, \mathrm{Mn}, \mathrm{Hg}$, dan $\mathrm{Zn}$ serta zat kimia seperti Pestisida, Sianida, Sulfida, Fenol dan sebagainya Logam-logam berat pada umumnya bersifat racun walaupun dalam konsentrasi rendah disebabkan oleh terkikisnya metal bantalan dan masuk dalam oli.

Perbuatan pidana yang dilakukan oleh orang perseorangan maupun korporasi perlu penanggulangan dan kepada pelaku dapat dipertanggungjawabkan perbuatannya secara pidana. Penelitian ini bertujuan untuk mengetahui bagaimana hukum positif yang mengatur tentang tindak pidana pengumpulan limbah B3 oli, bagaimana pertanggungjawaban pidana terhadap pelaku yang melakukan pengumpulan limbah B3 oli.

\section{Pembahasan}

\subsection{Hukum Positif yang Mengatur tetang Tindak Pidana Pengumpulan Limbah B3 Oli}

Otto Soemarwoto, Analisis Dampak Lingkungan, Press, Yogyakarta: Gadjah Mada University, 1994, hlm. 43.

Riyanto, Limbah Bahan Berbahaya dan Beracun (Limbah B3), Yogyakarta: Deepublish, 2014, hlm. 19.

Munadjat Danusaputro, Hukum Lingkungan dalam Pencemaran Lingkungan Melandasi Sistem Hukum Pencemaran, Buku V: Sektoral, Bandung: Bina Cipta, 1986, hlm. 77.

4 Akmadi, Zainal \& Suharno. "Efektifitas Limbah Rambut Dalam Menurunkan Kadar Minyak Oli Pada Air Limbah Bengkel." Jurnal Vokasi Kesehatan 3, no. 1 (2017), hlm. 18. 
Limbah Bahan Berbahaya dan Beracun yang selanjutnya disingkat B3 adalah zat, energi, dan/atau komponen lain yang karena sifat, konsentrasi, dan/atau jumlahnya, baik secara langsung maupun tidak langsung, dapat mencemarkan dan/atau merusak lingkungan hidup, dan/atau membahayakan lingkungan hidup, kesehatan, serta kelangsungan hidup manusia dan makhluk hidup lain. ${ }^{5}$ Bahan Berbahaya dan Beracun (B3) bersifat Limbah mudah meledak, Limbah mudah terbakar, Limbah beracun, Limbah yang menyebabkan infeksi, Limbah bersifat korosif, Limbah yang bersifat reaktif. Perlu diupayakan agar kegiatan industri penghasil limbah Bahan Berbahaya dan Beracun (B3) dapat mencegah masuknya limbah Bahan Berbahaya dan Beracun (B3) ke lingkungan kerja. ${ }^{6}$

Setiap orang yang menghasilkan limbah wajib melakukan pengelolaan, bila tidak sanggup melakukan pengelolaanya sendiri maka harus diserahkan kepada pihak lain. Pengelolaan limbah B3 disini meliputi pengurangan, penimbunan, penyimpanan, pengangkutan, dan/atau pemanfaatan. Pada dasarnya untuk melakukan pengelolaan limbah B3 diperbolehkan asalkan memiliki izin dari pemerintah.

Kegiatan usaha yang menimbulkan dampak besar dan penting terhadap lingkungan hidup wajib memiliki analisis mengenai dampak lingkungan hidup, memperoleh izin lingkungan sebagai prasyarat melakukan suatu kegiatan usaha. Izin lingkungan merupakan izin yang diberikan kepada setiap orang yang melakukan Usaha dan/atau Kegiatan yang wajib Amdal atau UKL-UPL dalam rangka perlindungan dan pengelolaan lingkungan hidup sebagai prasyarat memperoleh izin Usaha dan/atau Kegiatan. ${ }^{7}$ Setiap orang yang menjalankan usaha pengelolaan oli bekas wajib mendapat izin dari pemerintah dalam hal ini diperoleh melalui tahapan kegiatan penyusunan Amdal dan UKL-UPL, penilaian Amdal, dan pemeriksaan UKL-UPL dan permohonan dan penerbitan Izin Lingkungan. Oli bekas dikategorikan sebagai limbah bahan berbahaya dengan kode B105d dengan kategori bahaya 2 (dua). Untuk mengetahui Limbah B3 maka dilakukan uji TCLP. Pengujian dapat dilakukan dengan

a. karakteristik beracun melalui TCLP untuk menentukan limbah dengan konsentrasi zat pencemar lebih kecil dari atau sama dengan konsentrasi zat pencemar pada kolom TCLP-A dan TCLP-B. ${ }^{8}$

b. karakteristik beracun melalui Uji Toksikologi LD50 untuk menentukan Limbah yang diuji memiliki nilai Uji Toksikologi LD50 lebih besar dari 50 $\mathrm{mg} / \mathrm{kg}$ (lima puluh miligram per kilogram) berat badan hewan uji dan lebih kecil dari atau sama dengan $5000 \mathrm{mg} / \mathrm{kg}$ (lima ribu miligram per kilogram) berat badan hewan uji; dan/atau

c. karakteristik beracun melalui uji toksikologi subkronis menggunakan hewan uji mencit selama 90 (sembilan puluh) hari menunjukkan sifat racun subkronis.

Pengecekan limbah yang berbahaya dengan menggunakan TCLP (Toxicity Characteristic

Pasal 1 Ayat (1) Peraturan Pemerintah Nomor 101 Tahun 2014 tentang Pengelolaan Limbah Berbahaya dan Beracun

Azteria, Veza \& Jamal Efendi. "Identifikasi Keselamatan Penanganan Limbah Pelumas Pada PT. Altrak 1978 Balikpapan." Jurnal Biologi Lingkungan, Industri, Kesehatan 4, no. 1 (2017), hlm. 33.

7 Pasal 1 Ayat (1) Peraturan Pemerintah Nomor 27 tahun 2012 tentang Izin Lingkungan

8 Pasal 191 Ayat (4) Peraturan Pemerintah Nomor 101 Tahun 2014 tentang Pengelolaan Limbah Berbahaya dan Beracun 
Leaching Procedure) merupakan suatu metode pengujian digunakan untuk menentukan apakah limbah adalah bersifat berbahaya (limbah B3). TCLP terdiri dari empat prosedur, yaitu persiapan sampel untuk pencucian, pencucian sampel, persiapan lindi untuk analisis, dan analisis lindi. ${ }^{9}$ Pengelolan oli dari kegiatan pelapisan logam mencakup proses pelapisan logam pada permukaan logam secara elektris, Dari kegiatan pelapisan logam tersebut selain menghasilkan produk yang berguna, juga menghasilkan limbah berupa oli bekas yang mengandung senyawa-senyawa asam dan logamlogam tertentu bergantung pada sifat kegiatan pelapisan logam.

Limbah Oli bekas yang hasilkan dari proses pelapisan mesin memiliki kandungan logam berat seperti $\mathrm{Al}, \mathrm{Cr}, \mathrm{Cd}, \mathrm{Cu}, \mathrm{Fe}, \mathrm{Pb}, \mathrm{Mn}, \mathrm{Hg}$, dan $\mathrm{Zn}$ serta zat kimia seperti Pestisida, Sianida, Sulfida, Fenol dan sebagainya logam-logam berat pada umumnya bersifat racun walaupun dalam konsentrasi rendah disebabkan oleh terkikisnya metal bantalan dan masuk dalam oli. Logam $\mathrm{Pb}$ dalam minyak pelumas bekas dapat terlihat dari warna minyak pelumas yang semakin pekat. Jika minyak pelumas bekas tersebut tidak diolah terlebih dahulu maka akan masih mengandung logam $\mathrm{Pb}$ dimana logam $\mathrm{Pb}^{2+}$ yang terkandung dalam minyak pelumas bekas akibat pembakaran akan terlepas ke atmosfir kemudian akan jatuh ke laut mengikuti air hujan sehingga dapat menyebabkan pencemaran. ${ }^{10}$

Tabel 1

Bahan berbahaya Oli bekas

\section{Bahan Beracun}

Jenis Bahan

Akibat Keracunan dan

\section{Gangguan}

*Syaraf, ginjal dan darah

* Ginjal dansyaraf

* Hati, ginjal dandarah

* Kanker

* Iritasi dankanker

Logam/Metalloid

Cadmium, Cd

Ginjal, tulang, anemia ringan

Mercurium (Raksa), $\mathrm{Hg}$

Gangguan syaraf pusat, gangguan otak, teratogenik, sistem ginjal, sistem reproduksi

Batu ginjal, anemia, lever, cirrhosis, kanker, prostat gland.

Sumber: Suratmin Utomo konversi vol. 1 No1 April 2012

Dalam penelitian di atas dapat disimpulkan dikarenakan bahan yang bermanfaat bisa berubah limbah bahan berbahaya beracun ternyata banyak ditemukan di tengah- tengah kehidupan, baik sebagai bahan terpakai maupun konsumsi hal ini menjadi bahan berbahaya Jika pemakaiannya tidak tepat, kadaluarsa atau penangananya yang salah sehingga kita harus waspada terhadap bahan- bahan

9 Riyanto., Op.,Cit. hlm. 33.

10 Utomo, Suratmin. "Bahan Berbahaya dan Beracun (B-3) dan Keberadaanya di Dalam Limbah." Konversi 1, no. 1 (2012). HIm. 42. 
yang berada di sekeliling kita.

Hukum positif (ius constitutum) di Indonesia merupakan hukum tertulis yang pada saat ini sedang berlaku dan ditegakkan oleh pemerintah atau pengadilan. ${ }^{11}$ Adapun beberapa hukum positif yang mengatur tentang limbah B3 meliputi

1. Undang-Undang Nomor 32 Tahun 2009 tentang UUPPLH pada Pasal 102 jo 59 (4).

2. Peraturan Pemerintah Nomor 101 Tahun 2014 tentang Pengelolaan Limbah bahan Berbahaya dan Beracun pada Pasal 99 bahwa Setiap Orang yang menghasilkan Limbah B3, Pengumpul Limbah B3, Pengangkut Limbah B3, Pemanfaat Limbah B3, Pengolah Limbah B3, dan/atau Penimbun Limbah B3 yang melakukan Pencemaran Lingkungan Hidup dan/atau Perusakan Lingkungan Hidup wajib melaksanakan:

a. Penanggulangan pencemaran lingkungan hidup dan/atau kerusakan lingkungan hidup.

b. Pemulihan Fungsi Lingkungan Hidup

3. Peraturan Pemerintah Kota Medan Nomor 13 Tahun 2003 tentang izin pengelolaan dan pemanfaatan limbah pada Pasal 3 bahwa Setiap penanggung jawab usaha atau kegiatan yang melakukan pelanggaran maka pemerintah Kota melalui dinas menjatuhkan sanksi administrasi.

4. Perda Kota Medan Nomor 1 Tahun 2016 tetang Pengelolaan Limbah Bahan Berbahaya dan Beracun pada Pasal 27 dan 28 bahwa Setiap orang yang menghasilkan limbah B3 yang tidak memenuhi atau melakukan pelanggarandi kenakan sanksi administratif.

\subsection{Pertanggungjawaban Pidana Terhadap \\ Pelaku yang Melakukan Pengumpulan Limbah Bahan Berbahaya Beracun Oli}

Setiap orang yang melakukan perbuatan mengelola limbah oli B3 tanpa izin dari oleh menteri, gubernur, bupati/walikota sesuai dengan kewenangannya dapat dipidana. Hal ini tercantum di dalam Pasal 102 Undang-Undang Nomor 32 Tahun 2009 tentang UUPPLH bahwa "Setiap orang yang melakukan pengelolaan limbah B3 tanpa izin sebagaimana dimaksud dalam Pasal 59 ayat (4), dipidana dengan pidana penjara paling singkat 1 (satu) tahun dan paling lama 3 (tiga) tahun dan denda paling sedikit Rp. 1.000.000.000,00 (satu miliar rupiah) dan paling banyak Rp. 3.000.000.000,00 (tiga miliar rupiah)".

Perbuatan yang dilarang dalam Pasal 59 ayat 4 adalah Pengelolaan limbah B3 wajib mendapat izin dari Menteri, gubernur, atau bupati/walikota sesuai dengan kewenangannya. Unsur subyektif dari pasal 59 ayat 4 yaitu setiap orang baik itu orang perorangan maupun badan hukum. Orang perorangan maupun badan hukum dapat dipertanggungjawabkan pidana apabila

11 I. Gede Pantja Astawa, Dinamika Hukum dan ilmu Perundang-Undangan di Indonesia. Bandung: Alumni, 2008, hlm. 56. 
memiliki kesalahan (fault). Dalam teori pertanggungjawaban pidana terdapat dua aliran yaitu $: 12$

a. dalam aliran monistis, unsur-unsur strafbaarfeit merupakan unsur perbuatan yang lazim disebut unsur objektif, maupun unsur pembuat, yang lazim dinamakan unsur subjektif. Dengan demikian unsur perbuatan dan unsur pembuatnya merupakan satu kesatuan. Dengan demikian strafbaarfeit adalah sama dengan syarat-syarat penjatuhan pidana, sehingga seolaholah dianggap bahwa kalau terjadi strafbaar feit, maka pasti pelakunya dapat dipidana.

b. pandangan dualistis menentang kebenaran pendirian mengenai kesalahan (schuld) yang ketika itu berkuasa, yang beliau dinamakan "objective schuld", oleh karena kesalahan di situ dipandang sebagai sifat dari kelakuan (merkmal der handlung). Untuk adanya syarat-syarat penjatuhan pidana terhadap pembuat (strafvoraussetzungen) diperlukan lebih dahulu pembuktian adanya perbuatan pidana (strafbare handlung), lalu setelah itu dibuktikan schuld atau kesalahan subjektif pembuat.

Pertanggungjawaban pidana adalah diteruskannya celaan yang objektif yang ada pada tindak pidana dan secara subjektif kepada seseorang yang memenuhi syarat untuk dapat dijatuhi pidana karena perbuatannya itu, disyaratkan bahwa tindak pidana yang dilakukan itu harus memenuhi unsurunsur yang telah ditentukan undang-undang. ${ }^{13}$ Menurut Simon pertanggungjawaban pidana adalah suatu perbuatan yang oleh hukum diancam dengan hukuman, bertentangan dengan hukum, dilakukan bertanggungjawab atas perbuatannya.

Seorang dapat mempertanggungjawabkan perbuatannya apabila telah memenuhi unsur subjektif dan objektif pada Pasal 59 ayat (4). Unsur subyektif terdapat pada diri pelaku tindak pidana atau yang berhubungan dengan diri pelaku serta termasuk di dalamnya yaitu segala sesuatu yang terkandung di dalam hatinya, unsur subyektifnya meliputi:

a. Orang perorangan adalah setiap manusia sudah menjadi subyek hukum secara alami. Jika dipandang bahwa subyek hukum tidak cakap bertindak dalam hukum maka dalam melakukan perbuatan hukum mereka harus diwakili atau dibantu oleh orang lain yang cakap bertindak didalam hukum

b. Badan hukum adalah suatu badan yang terdiri dari kumpulan orang yang diberi status "persoon" oleh hukum sehingga mempunyai hak dan kewajiban. Badan hukum dapat menjalankan perbuatan hukum sebagai pembawa hak manusia.

Unsur obyektif merupakan unsur-unsur yang ada hubungannya dengan keadaan-keadaan, yaitu di dalam keadaan-keadaan mana tindakantindakan dari si pelaku itu harus di lakukan ${ }^{14}$ meliputi: Kesalahan adalah dasar untuk pertanggungjawaban. Kesalahan merupakan keadaan jiwa dari si pembuat dan hubungan batin antara si pembuat dan perbuatannya.

12 Muladi \& Dwidja Priyatno, Pertanggungjawaban Pidana Korporasi, Jakarta: Kencana, 2012, hlm. 63

13 Mahmud Mulyadi dan Feri Antoni Surbakti, Politik Hukum Pidana Terhadap Kejahatan Korporasi, Jakarta: Sofmedia, 2010, hlm. 34.

14 P.A.F. Lamintang, Dasar-dasar Hukum Pidana Indonesai, Bandung: Citra Aditya Bakti, 1997, hlm. 193. 
Adanya kesalahan pada seseorang, maka orang tersebut dapat dicela. Mengenai keadaan jiwa dari seseorang yang melakukan perbuatan merupakan apa yang lazim disebut sebagai kemampuan bertanggungjawab, sedangkan hubungan batin antara si pembuat dan perbuatannya itu merupakan kesengajaan, kealpaan, serta alasan pemaaf.

Kesalahan tersebut terdiri dari dua jenis yaitu kesengajaan (dolus) dan kelalaian (culpa):

1. Kesengajaan (dolus), Sesuai teori hukum pidana Indonesia, kesengajaan terdiri dari tiga macam, yaitu:

a. Kesengajaan (dolus) kesengajaan terdiri dari tiga macam yaitu Kesengajaan yang bersifat tujuan dengan adanya kesengajaan yang bersifat tujuan. Pelaku benar benar menghendaki mencapai suatu akibat yang menjadi pokok alasan diadakannya ancaman hukuman.

b. Kesengajaan secara keinsyafan kepastian perbuatannya tidak bertujuan untuk mencapai akibat yang menjadi dasar dan delik, tetapi ia tahu benar bahwa akibat itu pasti akan mengikuti perbuatan itu.

c. Kesengajaan secara keinsyafan kemungkinan, kesengajaan yang terang-terang tidak disertai bayangan suatu kepastian akan terjadi akibat yang bersangkutan, melainkan hanya dibayangkan suatu kemungkinan belaka akan akibat itu. Kealpaan merupakan bentuk dari kesalahan yang menghasilkan dapat dimintai pertanggungjawaban atas perbuatan seseorang yang dilakukannya. ${ }^{15}$

2. Kelalaian (culpa), kelalaian (culpa) terletak antara sengaja dan kebetulan, bagaimanapun juga culpa dipandang lebih ringan dibanding dengan sengaja, oleh karena itu delik culpa, culpa itu merupakan delik semu (quasideliet) sehingga diadakan pengurangan pidana. Delik culpa mengandung dua macam, yaitu delik kelalaian yang menimbulkan akibat dan yang tidak menimbulkan akibat, tapi yang diancam dengan pidana ialah perbuatan ketidakhati-hatian itu sendiri, perbedaan antara keduanya sangat mudah dipahami yaitu kelalaian yang menimbulkan akibat dengan terjadinya akibat itu maka diciptalah delik kelalaian, bagi yang tidak perlu menimbulkan akibat dengan kelalaian itu sendiri sudah diancam dengan pidana. ${ }^{16}$

Ketika konsep strict liability ditelaah lebih mendalam, maka sedikitnya ada dua pandangan yang saling bertolak belakang tentang hal ini. Pertama, sebagian pakar menyatakan bahwa pertanggungjawaban berdasar tanggung jawab mutlak adalah pertanggungjawaban pidana tanpa kesalahan (liabilitiy without fault). Dengan demikian,

15 Moeljatno, Perbuatan Pidana dan Pertanggung jawaban Dalam Hukum Pidana, Jakarta: Bina Aksara, 1993, hlm. 46.

16 Ibid, hlm. 48 
konsep ini adalah konsep Hukum Pidana Materiil, yaitu seseorang dikatakan bertanggung jawab atas suatu tindak pidana (actus reus) sekalipun tidak ada niat jahat atau kesalahan pada dirinya (mens rea).

Kedua, strict liability dipandang sebagai konsep Hukum Pidana Formil, yaitu kegiatan yang menimbulkan kerugian lingkungan hidup yang terjadi di areal kerjanya menjadi tanggung jawabannya, tanpa lebih jauh membuktikan pembuktian unsur kesalahan. Kesalahan (mens rea) yang bersangkutan tetap ada dan harus ada, hanya saja dianggap telah terbukti adanya, sepanjang tidak dapat dibuktikan sebaliknya.

Tindak pidana di bidang lingkungan hidup telah diatur secara khusus dalam Undang-Undang Nomor 32 Tahun 2009 tentang Perlindungan dan Pengelolaan Lingkungan Hidup (UUPPLH) bila terjadi tindak pidana yang tidak diatur dalam UUPPLH barulah ketentuan KUHP diberlakukan. ${ }^{17}$

Pengaturan pengelolaan limbah pada UUPPLH pada Pasal 102 :

Pasal 102 UUPPLH Bahwa setiap orang yang melakukan pengelolaan limbah B3 tanpa izin sebagaimana dimaksud dalam Pasal 59 ayat (4), dipidana dengan pidana penjara paling singkat 1 (satu) tahun dan paling lama 3 (tiga) tahun dan denda paling sedikit Rp 1.000.000.000,00 (satu miliar rupiah) dan paling banyak Rp 3.000.000.000,00 (tiga miliar rupiah).

Pasal tersebut merupakan delik formil. Pada Pasal 102 UUPPLH, asal pelakunya tidak memiliki surat izin pengelolaan limbah B3 dan tanpa perlu mempersoalkan adanya akibat dari perbuatan itu, maka pelakunya sudah dapat dipidana.

\section{Penutup}

Adapun yang menjadi kesimpulan dalam penelitian ini sebagai berikut

1. Setiap orang yang menghasilkan limbah wajib melakukan pengelolaan, bila tidak sanggup melakukan pengelolaanya sendiri maka harus diserahkan kepada pihak lain. Pada dasarnya untuk melakukan pengelolaan limbah B3 diperbolehkan asalkan memiliki izin lingkungan dari pemerintah. Hukum positif (ius constitutum) di Indonesia merupakan hukum tertulis yang pada saat ini sedang berlaku dan ditegakkan oleh pemerintah atau pengadilan. Hukum positif yang mengatur tentang larangan pengumpulan oli bekas diatur pada Pasal 102 Jo 59 (4) Undang-Undang Nomor 32 Tahun 2009 tentang UUPPLH. Pasal 99 Peraturan Pemerintah Nomor 101 Tahun 2014 tentang Pengelolaan Limbah bahan Berbahaya dan Beracun, Pasal 3 Peraturan Pemerintah Kota Medan Nomor 13 Tahun 2003 tentang izin pengelolaan dan pemanfaatan limbah pada, Pasal 27 dan 28 Perda Kota Medan Nomor 1 Tahun 2016 tetang pengelolaan limbah bahan berbahaya dan beracun.

2. Seorang dapat mempertanggungjawabkan perbuatannya apabila telah memenuhi unsur subyektif dan objektif pada Pasal 102 jo Pasal 59 ayat (4). Unsur subyektif adalah orang perorangan dan Badan hukum mempunyai hak dan kewajiban. Di dalam diri Pelaku terdapat kesalahan merupakan dasar untuk pertanggungjawaban. Seseorang dikatakan bertanggung jawab atas suatu tindak pidana (actus reus) sekalipun tidak ada niat jahat atau

17 Gatot Supramono, Penyelesaian Sengketa Lingkungan Hidup di Indonesia, Jakarta: Rineka Cipta, 2013, hlm. 144. 
kesalahan pada dirinya (mensrea). Dengan menggunakan Strict liability dipandang sebagai konsep Hukum Pidana Formil, yaitu kegiatan yang menimbulkan kerugian lingkungan hidup yang disebabkan oleh perbuatan pengumpulan atau pengelolaan limbah B3 yang di kategorikan sebagai oli tidak memiliki izin menjadi tanggung jawabannya, tanpa dibuktikan unsur kesalahan pada perbuatannya. Kesalahan (mensrea) yang bersangkutan tetap ada dan harus ada, hanya saja dianggap telah terbukti, sepanjang tidak dapat dibuktikan sebaliknya. Pada Pasal 102 UUPPLH apabila pelaku tidak memiliki surat izin pengelolaan limbah B3 dalam pasal tersebut tanpa mempersoalkan akibat perbuatan pelaku maka pelaku dapat dipidana. Dalam penegakan hukum hendaknya memperhatikan tiga aspek penegakan hukum yaitu keadilan, kepastian, dan kemanfaatan sehingga dapat terwujud penegakan hukum yang berkeadilan.

\section{DAFTAR PUSTAKA}

\section{A. Buku}

Danusaputro, Munadjat. Hukum Lingkungan dalam Pencemaran Lingkungan Melandasi Sistem Hukum Pencemaran, Buku V: Sektoral. Bandung: Bina Cipta, 1986.

Lamintang, P.A.F. Dasar-dasar Hukum Pidana Indonesai. Bandung: Citra Aditya Bakti, 1997.

Mahmud, Mulyadi \& Surbakti Feri Antoni. Politik Hukum Pidana Terhadap Kejahatan Korporasi. Jakarta: Sofmedia, 2010.

Moeljatno. Perbuatan Pidana dan Pertanggung jawaban Dalam Hukum Pidana. Jakarta: Bina Aksara, 1993.

Muladi \& Priyatno Dwidja. Pertanggungjawaban Pidana Korporasi. Jakarta: Kencana, 2012.

Pantja, Astawa I. Gede, and I. Gede Pantja Astawa. Dinamika Hukum dan ilmu PerundangUndangan di Indonesia. Bandung: Alumni, 2008.

Riyanto. Limbah Bahan Berbahaya dan Beracun (Limbah B3). Yogyakarta: Deepublish, 2014.

Soemarwoto, Otto. Analisis Dampak Lingkungan. Yogyakarta: Gadjah Mada University Press, 1994.

Suparmono, Gatot. Penyelesaian Sengketa Lingkungan Hidup di Indonesia. Jakarta: Rineka Cipta, 2013.
B. Jurnal

Akmadi, Zainal \& Suharno. "Efektifitas Limbah Rambut Dalam Menurunkan Kadar Minyak Oli Pada Air Limbah Bengkel." Jurnal Vokasi Kesehatan 3, no. 1 (2017).

Azteria, Veza \& Jamal Efendi. "Identifikasi Keselamatan Penanganan Limbah Pelumas Pada PT. Altrak 1978 Balikpapan." Jurnal Biologi Lingkungan, Industri, Kesehatan 4, no. 1 (2017).

Utomo, Suratmin. "Bahan Berbahaya dan Beracun (B-3) dan Keberadaanya di Dalam Limbah." Konversi 1, no. 1 (2012).

\section{Peraturan Perundang-undangan}

Undang-Undang Nomor 32 Tahun 2009 tentang Pengelolaan dan Perlindungan Lingkungan Hidup

Peraturan Pemerintah Nomor 101 Tahun 2014 tentang Pengelolaan Limbah Berbahaya Dan Beracun.

Peraturan Pemerintah Nomor 27 tahun 2012 tentang Izin Lingkungan.

Peraturan Daerah Kota Medan Nomor 1 Tahun 2016 tetang Pengelolaan Limbah Bahan Berbahaya Dan Beracun.

Peraturan Daerah Kota Medan Nomor 13 Tahun 2003 tentang Izin Pengelolaan Dan Pemanfaatan Limbah. 